\title{
Volcanic-related alteration and geochemistry of Iwodake volcano, Satsuma-Iwojima, Kyushu, SW Japan
}

\author{
S. Hamasaki \\ Research Center for Deep Geological Environments, Geological Survey of Japan, AIST, Central 7, 1-1-1 Higashi, Tsukuba 305-8567, Japan
}

(Received January 25, 2001; Revised September 26, 2001; Accepted January 11, 2002)

\begin{abstract}
Satsuma-Iwojima is located near the northwestern margin of Kikai caldera, and active Mt. Iwodake is one of the post-caldera cones. Inside the summit crater of about $300 \mathrm{~m}$ diameter and $50 \mathrm{~m}$ depth, volcanic gas with maximum temperature $>800^{\circ} \mathrm{C}$ is discharged. At Iwodake, the rhyolite is strongly altered by volcanic vapor and acid hydrothermal solution inside and around the summit crater. The main alteration mineral assemblages at surface include quartz-tridymite-cristobalite, tridymite-cristobalite-alunite and cristobalite-(alunite) inside the summit crater and on the ank. Molybdenum blue sublimates are forming at the surface around high-temperature fumaroles inside the summit crater. The ground surface is commonly cemented by amorphous silica or cristobalite. The original rhyolite with $\mathrm{SiO}_{2}=71-72 \mathrm{wt} \%$ has been leached, resulting in a rock with maximum $\mathrm{SiO}_{2}=97$ wt $\%$. All major elements are leached except for $\mathrm{TiO}_{2}$. Although LIL (large-ion lithophile) elements have leached, HFS (high eld-strength) elements appear to be immobile. Rare earth elements are considered to have been soluble as a complex with sulfate mainly in the low $\mathrm{pH}$ hydrothermal uid during the silici cation of the rhyolite. There is abundant $\mathrm{Mo}, \mathrm{Pb}, \mathrm{Zn}, \mathrm{Bi}, \mathrm{Sn}$ and much lower $\mathrm{As}$ in the volcanic sublimates and altered rocks inside the summit crater. By contrast, the rocks near the acid springs at the foot of the cone are As-rich, but with lower $\mathrm{Pb}, \mathrm{Zn}, \mathrm{Bi}$ and little Mo in comparison with the summit. The fractures and fumarole locations around Iwodake summit and erosional ridges on the anks re ects a NE-SW trend that is parallel to the trace of the outer ring of Kikai caldera. In addition, this is the same direction as the alignment of Shin-Iwojima, Iwodake and Inamuradake, all of which are post-caldera cones. Zones of structural weakness parallel to the caldera rim may exist, acting as pathways for the ascending volcanic gases and hydrothermal solutions. Fumarolic activity appears to be shifting gradually to the eastern part of the summit crater.
\end{abstract}

\section{Introduction}

Satsuma-Iwojima is an active volcano island located 40 $\mathrm{km}$ south of the Satsuma Peninsula in Kyushu, southwest Japan. The island is part of the Quaternary volcanic front of the Ryukyu arc. The volcanic island lies on the northwestern margin of the Kikai caldera (Matsumoto, 1937), a submarine caldera about $17 \mathrm{~km}$ in diameter (Fig. 1). Two post-caldera volcanoes, Inamuradake and Iwodake, occur on SatsumaIwojima. Iwodake is the largest volcano, with a roughly conical shape, an elevation of $704 \mathrm{~m}$, and a summit crater $300 \mathrm{~m}$ wide and $50 \mathrm{~m}$ deep. Many fumaroles exist within and outside the crater, and on the volcano ank. Native sulfur was historically mined inside the crater of Iwodake, and silica stone was quarried near the summit until 1996. Various aspects of Iwodake have been long studied, for example, geology (Matsumoto, 1937; Ono et al., 1982), alteration mineralogy (Yoshida et al., 1976; Kimbara et al., 1977), rock chemistry (Ueda and Itaya, 1981; Notsu et al., 1987), the composition of the volcanic gas and hot springs (Kamada et al., 1974; Nogami et al., 1993; Shinohara et al., 1993; Hedenquist et al., 1994a) and isotopic geochemistry (Matsuo et al., 1974; Matsubaya et al., 1975). Saito (1998)

Copy right (C) The Society of Geomagnetism and Earth, Planetary and Space Sciences (SGEPSS); The Seismological Society of Japan; The Volcanological Society of Japan; The Geodetic Society of Japan; The Japanese Society for Planetary Sciences. published a topographical map of the summit crater area.

Alteration mineral assemblages are helpful in recording the volcanic activity and its characteristics. In addition, the behavior of metals and other components related to volcanic activity provides information on the hydrothermal processes related to the formation of ore deposits (Hedenquist et al., 1994a). This study contributes additional information on the mineralogy and geochemistry of alteration of Iwodake, and the geological structure inside and around the summit crater.

\section{Geological Setting}

The geology of the island is dominated by volcanic products related to the caldera (Fig. 1(c)). The caldera boundary intersects the island NE-SW. Pre-caldera units occur outside the caldera margin and consist of andesite-basalt (Yahazuyama) and rhyolite lavas (Nagahama). Pyroclastic products of the caldera-forming eruption (Koabiyama and Takeshima pyroclastic ow deposits) are preserved in the northwest part of the island. The eruption that accompanied the Takeshima pyroclastic deposit also ejected "Akahoya" about 6300 years ago, a well-known ne air-fall ash that is used as a standard tephra in Japan (Machida and Arai, 1978). Post-caldera units include the basaltic Inamuradake volcano and rhyolitic Iwodake volcano. Iwodake is a steep rhyolite ow-dome complex with bedded volcaniclastics, talus and a few air-fall scoria and pyroclastic ow deposits. The ${ }^{14} \mathrm{C}$ 


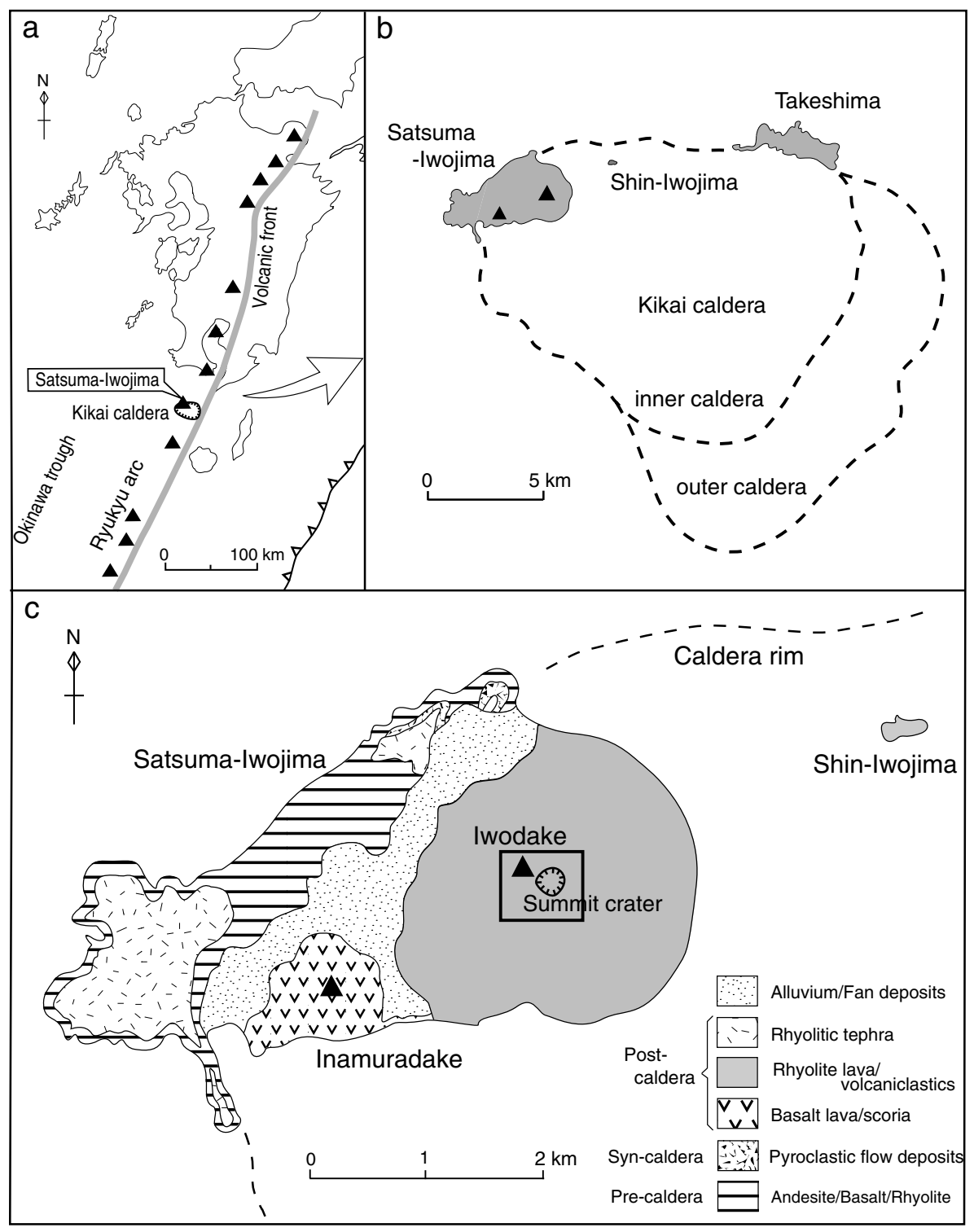

Fig. 1. a, b) Location of Quaternary volcanic front of Ryukyu arc, Kikai caldera and Satsuma-Iwojima. Kikai caldera consists of inner and outer rims. c) Geological map of Satsuma-Iwojima (simplified from Ono et al., 1982). Square shows area of Figs. 2 and 3.

ages of the pyroclastic flow deposits are 1500-1300 yrBP (Ono et al., 1982) and 500-600 yrBP (Kawanabe, 2000). Iwodake rhyolite overlies the Inamuradake basalt that finished eruption at the latest 3000 years ago. According to these geological and geochronological data, Iwodake started to erupt on a large scale about 3000 years ago, and subsequently erupted several times with lava, volcaniclastics and pyroclastic flows. According to an ancient document, the fumarole activity atop Iwodake has continued for more than 1000 years.

\section{Distribution and Mineral Assemblages of Alter- ation}

Numerous fumaroles exist in and around the summit crater of Iwodake (Fig. 2). The temperature of the fumaroles varies from about $100^{\circ} \mathrm{C}$ to $>800^{\circ} \mathrm{C}$ (Shinohara et al., 1993). The vapor in the fumaroles consists mainly of water and volcanic gases such as $\mathrm{SO}_{2}, \mathrm{HCl}, \mathrm{CO}_{2}, \mathrm{H}_{2} \mathrm{~S}$ and
HF (Matsubaya et al., 1975). The distribution of the fumaroles is focused in the NE-SW direction (Fig. 2). The original rock of Iwodake is rhyolite lava and volcaniclastic products. The alteration minerals in the main samples collected for this study are listed in Table 1 . The main alteration mineral zones and mapped structures in the summit area, including the Ohtanibira and Kotake silica quarry remnants, are shown in Fig. 3.

\subsection{Inside the summit crater}

Inside the summit crater, the fumaroles are widely distributed. The Ohachi vent (Shinohara et al., 1999) has been active since 1996, with a diameter increasing to $50 \mathrm{~m}$, and now degasses the largest amount of volcanic gas. The maximum temperature of the vent was $862^{\circ} \mathrm{C}$ in 1997 (G.S.J. and Kyoto University, 1998). The texture of the altered rock here poorly preserves that of the original ryholite, and very strongly residual silicified rocks are porous to friable. The residual silicified rock is composed mainly of 


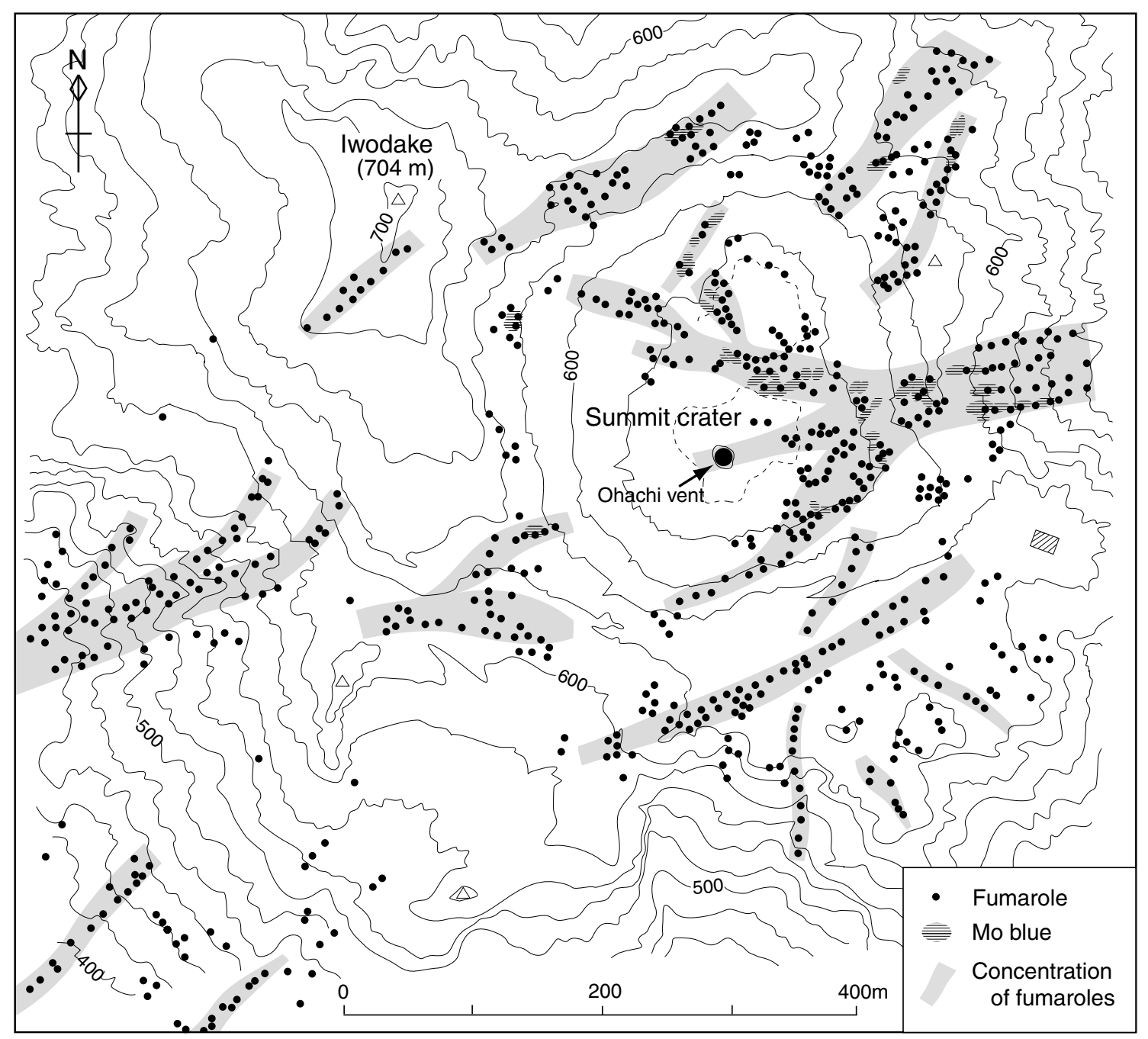

Fig. 2. Distribution of fumaroles around the Iwodake summit crater. Topographic map is from Saito (1998).

quartz, $\alpha$-cristobalite, tridymite (low-temperature type) and native sulfur. A blue sublimate, called molybdenum blue, covers residual silicified rock adjacent to high-temperature fumaroles (Fig. 4(a)), and quartz is also more abundant. Molybdenum blue is an amorphous hydrate with $\mathrm{Mo}^{5+}$ and $\mathrm{Mo}^{6+}$ (Yoshida et al., 1972) that has been documented near high-temperature fumaroles. Compared to the center of the crater, the walls of the crater contain less quartz and more tridymite. Alunite and clay minerals have not been documented inside the crater or on the crater wall.

\subsection{Outside the summit crater}

Numerous fumaroles also occur outside the summit crater. The main alteration minerals in this area are $\alpha$-cristobalite and tridymite, together with lesser amounts of native sulfur, sometimes alunite and rare quartz. Overall, residual silicification outside the crater is less intense than inside. By contrast, alunite is abundant outside of the crater. On the ground surface clay minerals were not found around the summit crater.

Outside the crater walls, the abandoned Ohtanibira and Kotake silica quarries provide good views of the altered rhyolite. Alunite filling the matrix of talus is also commonly observed at the quarries. At an outcrop in Kotake, located about $10 \mathrm{~m}$ under the original surface at an elevation of $620 \mathrm{~m}$, similar amounts of cristobalite and alunite are present. At an outcrop in Ohtanibira, located more than $50 \mathrm{~m}$ under the original surface at an elevation of $600 \mathrm{~m}$ and farther from the summit crater rim, alunite is much more abundant.

\subsection{Flank}

Some fumaroles also occur on the flank of the volcano, although they are fewer than inside and around the summit crater (Fig. 2). Compared with the summit, flank fumaroles seem to consist largely of water vapor, based on their odor. The alteration mineralogy on the flank is mostly cristobalite, and sometimes accompanied by amorphous silica, rare alunite and kaolinite.

\subsection{Ground surface around the crater and the flank}

Around the summit crater and on the flank of Iwodake, silicification, as silica addition, of volcaniclastics, ash and talus is observed on the surface far from fumaroles (Fig. 4(b)). Although the thickness of the silica-added layer is variable, it is usually greater than several tens of $\mathrm{cm}$. Silicification becomes weaker at lower elevations. The silicaadded layer is composed of amorphous silica and cristobalite. 


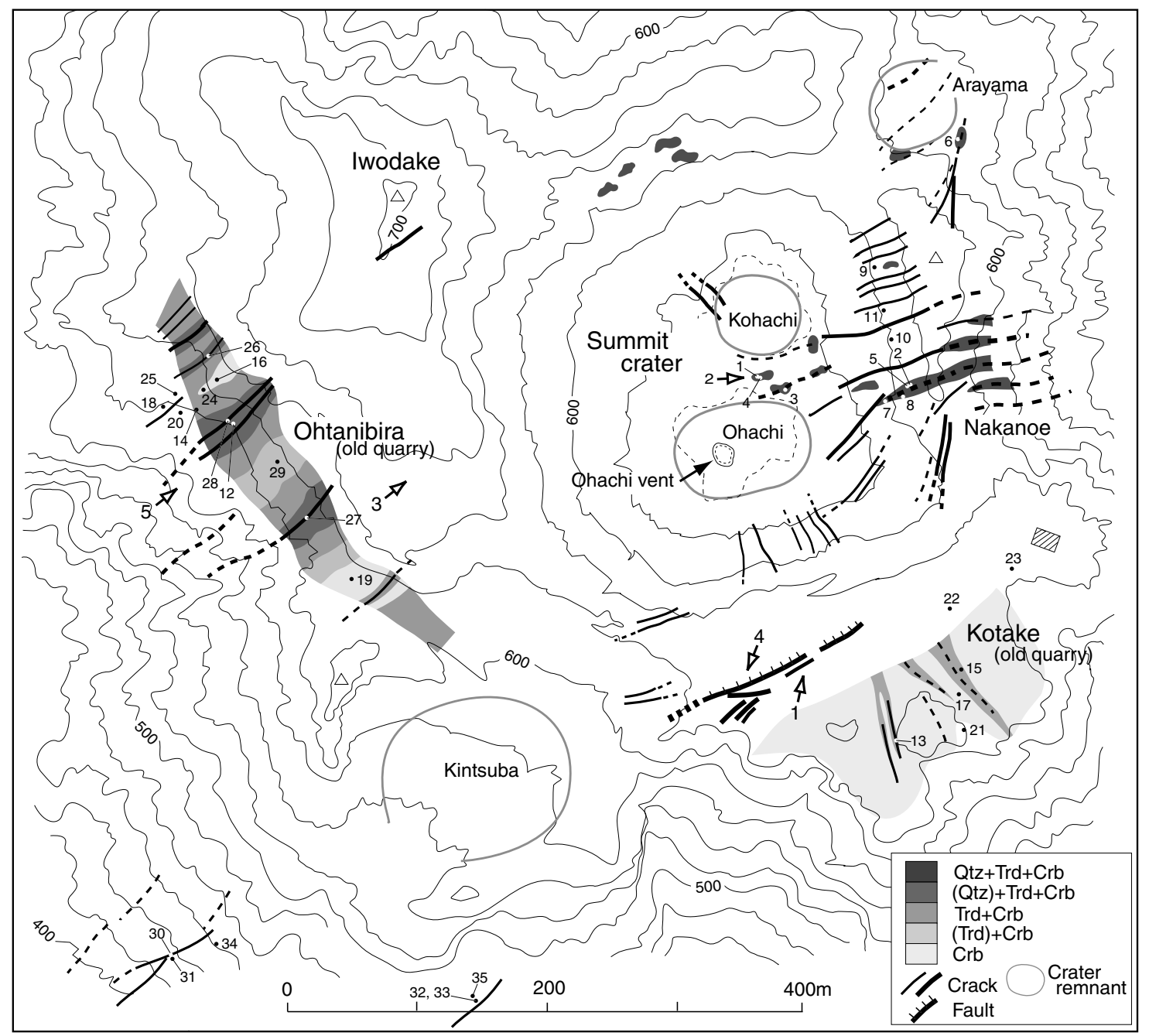

Fig. 3. Distribution of fractures and strongly altered zones around the Iwodake summit crater. Minerals in legend show alteration mineral assemblages. Numbered arrow shows photograph number and angle of Fig. 4. Thick and thin lines refer to different widths of fractures, and broken line shows an inferred fracture. The fault near arrow no. 4 indicates the northern downfaulted side.

\subsection{Fractures}

There are many fractures with varying widths inside and around the summit crater. Although the fractures are typically less than $20 \mathrm{~cm}$ wide, some open fractures up to $60 \mathrm{~cm}$ wide are offset about $80 \mathrm{~cm}$ down to the north on the southern side of the crater rim (Fig. 4(c)). Some groups of sulfur chimneys are also present along the fractures (Fig. 4(d)).

Fractures occur in two principal directions, NE-SW and NW-SE. The NE-SW direction is much clearer. The Ohtanibira and Kotake silica stone quarries expose cross sections more than $250 \mathrm{~m}$ and $200 \mathrm{~m}$ wide and about $40 \mathrm{~m}$ and $15 \mathrm{~m}$ high, respectively. In addition, there is a good cross section in the Nakanoe area along the eastern wall inside the summit crater. There are many NE-SW fractures in these areas, which acted as conduits of hydrothermal solution, and alteration zones have developed vertically along the fractures (Figs. 3 and 4(e)). The alteration zoning outward from the central fracture is characterized by the following pattern: (quartz)-tridymite- $\alpha$ cristobalite, tridymite$\alpha$ cristobalite, (tridymite)- $\alpha$ cristobalite and $\alpha$ cristobalite. Quartz occurs locally along open fractures. In addition, many amorphous silica veins fill cracks up to $3 \mathrm{~cm}$ wide in the silicified rocks. There are also NW-SE fractures inside and around the summit crater, but they are few and not as abundant as the NE-SW fractures.

\section{Chemistry of Altered Rocks}

Table 2 shows the major and trace elements, including rare earth element (REE) content, of altered rock, and Table 3 shows the metal content of selected samples. Unaltered rocks and a variety of altered rocks representative of various locations inside and around the summit crater of Iwodake volcano were chosen for the purpose of understanding the chemical behavior of elements during hydrothermal alteration, including rocks from the flank, near fractures and molybdenum blue-bearing rock.

\subsection{Major element}

Figure 5 shows major element variations versus $\mathrm{SiO}_{2}$. Unaltered rocks of Iwodake are rhyolite with 71-72 wt\% $\mathrm{SiO}_{2}$. The rhyolite has been leached of most components except silica by acidic magmatic-hydrothermal fluids, with the residual silica reaching $97 \mathrm{wt} \% \mathrm{SiO}_{2}$. The $\mathrm{Al}_{2} \mathrm{O}_{3}, \mathrm{Fe}_{2} \mathrm{O}_{3}$ and 
Table 1. Alteration mineral assemblages inside and around the summit crater and on the ank of Iwodake.

\begin{tabular}{|c|c|c|c|c|c|c|c|c|c|c|}
\hline No. & Sample & Locality & occurrence & $\mathrm{S}$ & Qtz & Trd & $\alpha \mathrm{Crb}$ & Alu & Am. Si & $\mathrm{Pl}$ \\
\hline 1 & SIJ-2 & Inside summit crater & Mo blue center & + & +++ & ++++ & ++++ & & & \\
\hline 2 & $022403-1$ & (central part) & Mo blue center & + & ++++ & ++ & ++ & & & \\
\hline 3 & $022409-1$ & & Mo blue center & & ++ & + & +++ & & & \\
\hline 4 & SIJ-1 & & Mo blue & & ++ & +++ & +++ & & & \\
\hline 5 & $022403-2$ & & Mo blue & - & +++ & ++ & + & & & \\
\hline 6 & $022401-3$ & & Mo blue (Arayama) & & ++ & ++ & ++ & & & \\
\hline 7 & 98110813 & Inside summit crater & Fine crumbly silici ed rock & - & +++ & +++ & +++ & & & \\
\hline 8 & 98110923 & (crater wall) & Fine crumbly silici ed rock & + & +++ & +++ & +++ & & & \\
\hline 9 & 98110916 & & Coarse crumbly silici ed rock & + & + & ++++ & & & & \\
\hline 10 & 98110919 & & Strongly silici ed rock & + & ++ & ++++ & +++ & & & \\
\hline 11 & 98110917 & & Medium silici ed rock & + & + & - & +++ & & & \\
\hline 12 & 98110801 & Around summit crater & Strongly silici ed rhy. lava & - & + & +++ & +++ & & & \\
\hline 13 & 99112111 & & Strongly silici ed rhy. lava & & & + & ++++ & & - & \\
\hline 14 & 98110802 & & Medium silici ed rhy. lava & & & ++ & ++++ & & + & \\
\hline 15 & 99112104 & & Medium silici ed rhy. lava & & & ++ & +++ & & + & \\
\hline 16 & 98110805 & & Weakly silici ed rhy. lava & & & & +++ & & - & \\
\hline 17 & 99112103 & & Weakly silici ed rhy. lava & & & ++ & +++ & & + & \\
\hline 18 & 98110804 & & Weakly silici ed rock & & & + & ++++ & & + & \\
\hline 19 & 98111011 & & Weakly silici ed rock & & & & +++ & & + & \\
\hline 20 & 98110803 & & Unaltered rhyolite lava & & & + & +++ & & & ++ \\
\hline 21 & 99112102 & & Unaltered rhyolite lava & & + & ++ & ++ & & & ++ \\
\hline 22 & 98111113 & Below the surface & Sediment by meteoric water & & & - & +++ & + & - & \\
\hline 23 & $98110811-1$ & $($ Kotake $;<10$ m $)$ & Matrix of talus breccia & & & & + & +++ & & \\
\hline 24 & 98111134 & Below the surface & Matrix of talus breccia & & & & + & ++++ & & \\
\hline 25 & 98111121 & (Ohtanibira; $<40$ m) & Matrix of talus breccia & & & & - & ++++ & & \\
\hline 26 & $99112011^{\prime}$ & Along fracture & Strongly silici ed rock & & + & +++ & +++ & & - & \\
\hline 27 & $98111014^{\prime}$ & (around summit crater) & Crumbly silici ed rock & & ++++ & ++ & ++ & & - & \\
\hline 28 & $98110801^{\prime}$ & Amorphous silica vein & White vein & & & & & & ++ & \\
\hline 29 & 98111005 & (around summit crater) & White vein & - & & - & +++ & & + & \\
\hline 30 & 99112004 & Amor. silica. v. ( ank) & White vein & & & - & + & & ++ & \\
\hline 31 & 99112003 & Flank & Coarse crumbly silici ed rock & & - & - & ++++ & & - & \\
\hline 32 & 98111004 & & Coarse crumbly silici ed rock & & - & - & ++++ & & - & \\
\hline 33 & 98111003 & & Matrix of talus sediment & & & & +++ & - & + & \\
\hline 34 & 98111001 & & Matrix of talus sediment & & & & ++++ & & - & \\
\hline 35 & $98111003^{\prime}$ & & Layered boundary of talus sediment & & & & +++ & & + & \\
\hline
\end{tabular}

++++ : abundant, +++ : common, ++ : local, + : rare, - : very rare.

$\mathrm{S}$ : native sulfur, Qtz: quartz, Trd: tridymite, $\alpha \mathrm{Crb}: \alpha$-cristobalite, Alu: alunite, Am. Si: amorphous silica, Pl: plagioclase.

$\mathrm{K}_{2} \mathrm{O}$ all show similar patterns of depletion. These components decrease with increasing $\mathrm{SiO}_{2}$ content as leaching becomes more intense. The $\mathrm{CaO}, \mathrm{Na}_{2} \mathrm{O}, \mathrm{MgO}$ and $\mathrm{MnO}$ contents also show common depletion patterns, and are totally leached at about $\mathrm{SiO}_{2} 85 \mathrm{wt} \%$. $\mathrm{P}_{2} \mathrm{O}_{5}$ is not fully depleted, and the $\mathrm{TiO}_{2}$ content in lava remains constant. These data indicate that all major elements except for $\mathrm{TiO}_{2}$ and $\mathrm{P}_{2} \mathrm{O}_{5}$ have been essentially leached at a $\mathrm{SiO}_{2}$ content of $90 \mathrm{wt} \%$.

\subsection{Trace elements}

Figure 6 shows selected trace element variations versus $\mathrm{SiO}_{2}$ for the same altered samples as shown in Fig. 5. The $\mathrm{Sr}, \mathrm{Rb}, \mathrm{Sc}, \mathrm{Y}$, Th and $\mathrm{V}$ all decrease with increasing silica content. Compared with the major elements, the decrease is more gradual with full depletion not occurring until maximum $97 \mathrm{wt} \% \mathrm{SiO}_{2}$. The $\mathrm{Ba}, \mathrm{Zr}, \mathrm{Nb}$ and $\mathrm{Hf}$ show no clear pattern or is almost constant.

\subsection{REE}

Figure 7 shows REE patterns for altered rocks. Patterns in Fig. 7(a) are chondrite-normalized, and patterns in Fig. 7(b) are normalized to unaltered rhyolite from Iwodake. Unaltered to strongly silici ed rocks of rhyolite samples lava-1 and lava- 2 show a different of degree alteration in the same lava unit. Two unaltered samples show identical chondritenormalized REE patterns. The chondrite-normalized REE patterns of all altered samples show almost equal depletion in all REE except for Eu, which decreases more rapidly with increasing intensity of silici cation. In the same samples, the negative Eu anomaly, which is weak in the unaltered rhyolites, becomes greater. The unaltered rhyolite-normalized patterns show the transition of the REE depletion well, particularly Eu. It appears that Eu is almost entirely leached once the $\mathrm{SiO}_{2}$ content reaches about $90 \mathrm{wt} \%$. These patterns also show that leaching of light REEs is slightly greater than the heavy REEs.

\subsection{Metal contents}

The concentrations in ppm of several metals for representative samples are shown in Fig. 8. There is a greater degree of variability among metals than major or trace el- 

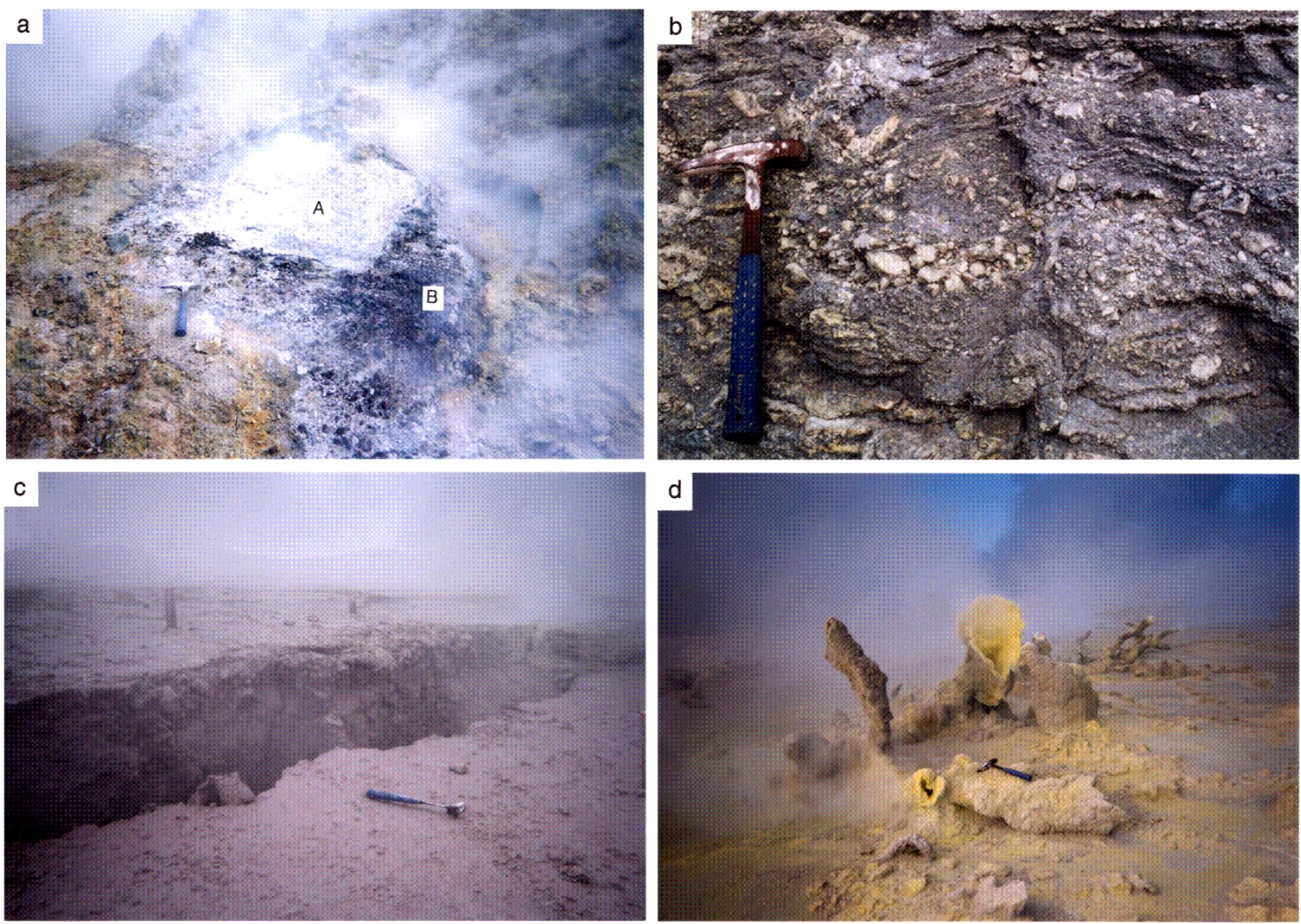

Fig. 4. a) Molybdenum blue sublimate inside the summit crater. A is the white central part having an abundant amount of secondary quartz, B is a typical blue part where many metals precipitated. b) Layered volcaniclastic rocks with matrix cemented by amorphous silica on the surface. c) Fault with ENE direction on the south side of the summit crater rim. The fault opened to a maximum width of about $60 \mathrm{~cm}$, and the northern side has a maximum of 80 $\mathrm{cm}$ downfault. d) A group of sulfur chimneys developed in the ENE direction on the south of the summit crater.

ements. The highest concentrations occur in samples from molybdenum blue sublimate areas (Figs. 8(a), (b)). In these samples, $\mathrm{Hg}$, As, Sn, W, Mo, Pb, Zn and $\mathrm{Bi}$ are all high, with the last four showing concentrations of several hundred ppm. In the silicified breccia inside the crater (Fig. 8(c)), $\mathrm{Mo}, \mathrm{Pb}, \mathrm{Bi}$ and $\mathrm{As}$ are strongly enriched relative to the unaltered rhyolite (Fig. 8(f)). Amorphous silica (Fig. 8(d)) has high $\mathrm{Zn}$, some $\mathrm{Pb}$ and no other metals. Strongly altered rhyolite lava (Fig. 8(g)) has a small amount of $\mathrm{Zn}, \mathrm{Pb}, \mathrm{Cu}$ and Mo with no other elements compared with the unaltered rhyolite lava. Samples of silicified matrix of talus near the $\mathrm{pH}$ 1.5 Higashi hot spring have abundant $\mathrm{Fe}$ and $\mathrm{Hg}$, and anomalous amounts of $\mathrm{As}, \mathrm{Pb}$ and $\mathrm{Zn}$. Hedenquist et al. (1994a) reported several ppm As, Pb, Mo, Sn, slightly lower $\mathrm{Zn}, 10^{-2} \mathrm{ppm} \mathrm{Sb}, \mathrm{Cu}$ and $10^{-6} \mathrm{ppm} \mathrm{Au}$ in high-temperature $\left(>700^{\circ} \mathrm{C}\right.$ ) fumarolic vapor. The relative contents of $\mathrm{Pb}, \mathrm{Zn}$, Mo and Sn, except for As and Mo, in the molybdenum blue sublimates are almost similar to their proportions in the high-temperature fumaroles, with the former showing concentrations of 10 to $10^{3}$ times the latter.

\section{Discussion and Conclusion}

\subsection{Alteration minerals}

Figure 9 shows assemblages of the alteration minerals inside and around the summit crater and on the flanks of Iwodake. Overall, the alteration mineral sequence of quartztridymite-cristobalite $\rightarrow$ tridymite-cristobalite-alunite $\rightarrow$ cristobalite-(alunite) is zoned from the inside to the outside of the summit crater and down the flank, respectively. Quartz is dominant particularly near the molybdenum blue sublimates. These assemblages, except for alunite, are also observed zoned around fractures (Figs. 3 and 4(e)). Therefore, the intensity of alteration depends on the location with the summit crater, and proximity to fractures inside and outside the crater. In general, native sulfur occurs as a volcanic sublimate near the fumaroles regardless of location inside or outside the summit crater. Molybdenum blue sublimates are produced only near high-temperature fumaroles, as mentioned above. Yoshida et al. (1972) calculated thermodynamically that a fumarole temperature of more than $500^{\circ} \mathrm{C}$ is necessary to form the molybdenum blue, which is consistent with its occurrence.

Thus, surface alteration at Iwodake is classified mainly into two types. The first type of alteration occurs inside and around the summit crater and formed by strongly acid solution or fumarole, consisting of residual silica accompanied by native sulfur and molybdenum blue. The strongly acid hydrothermal solution is formed by condensation of 


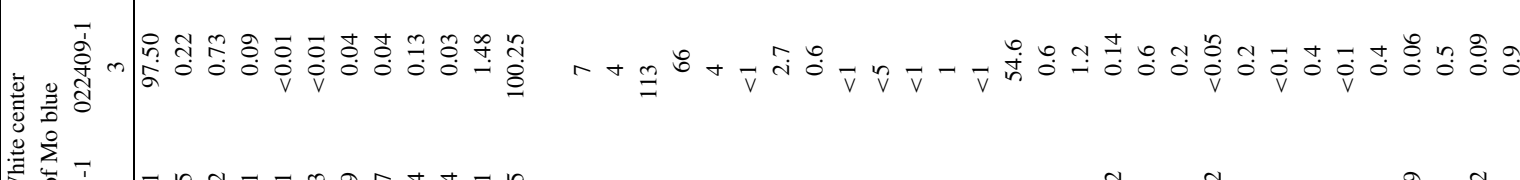

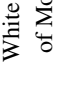

辛

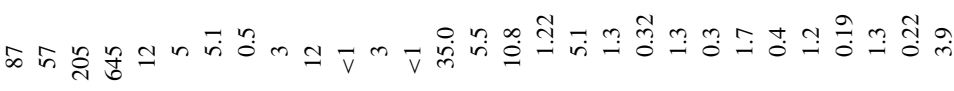

> 술 站

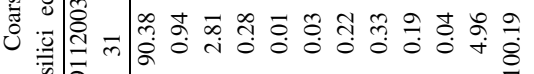
(

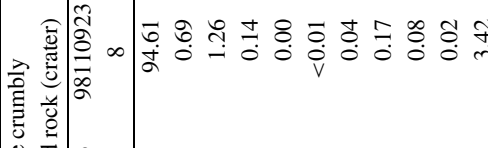

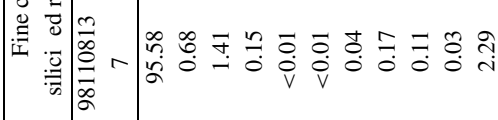

$\exists$

总

is.

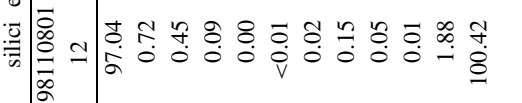
(1)

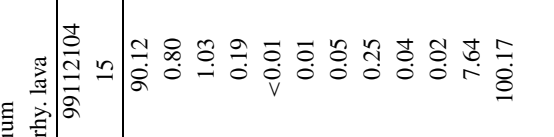

害

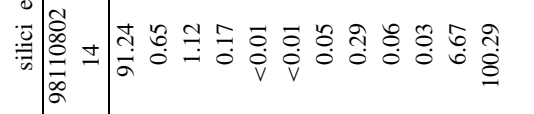

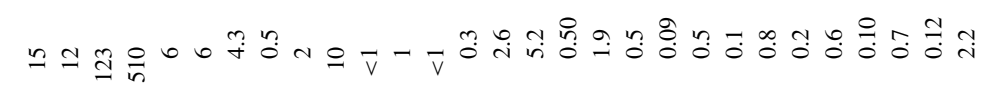

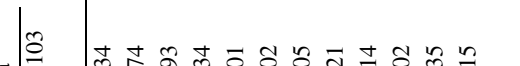

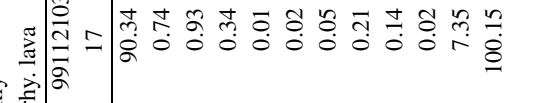

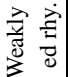

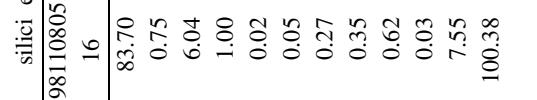

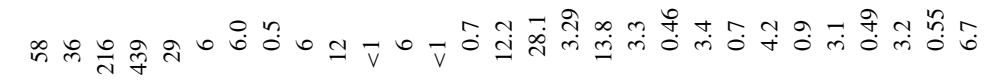

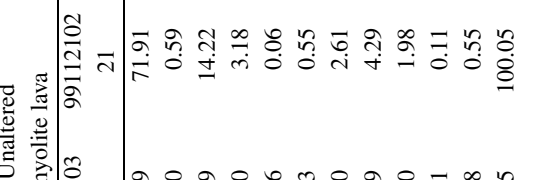

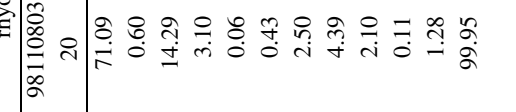
完

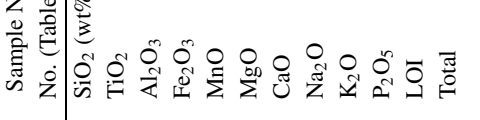

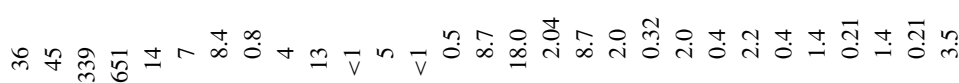

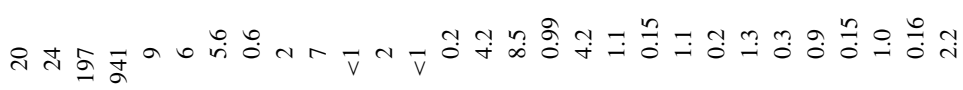
+

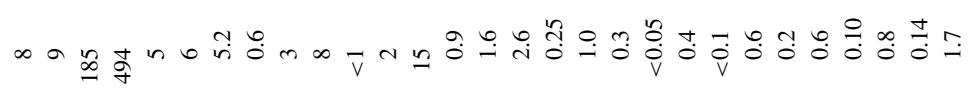

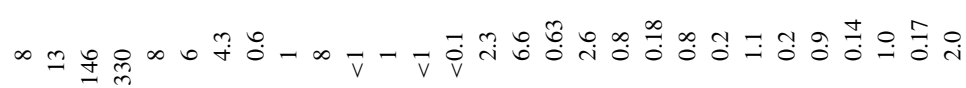

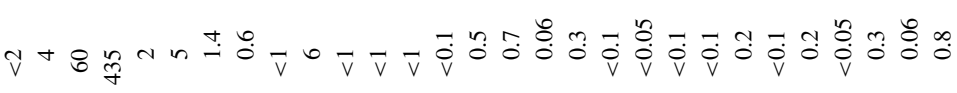

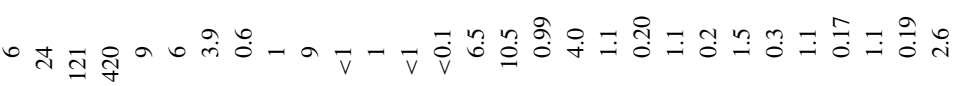

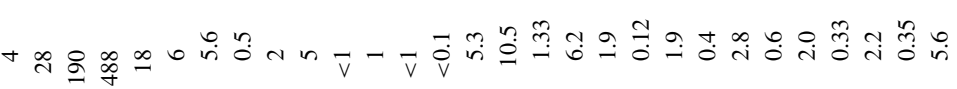
तमें

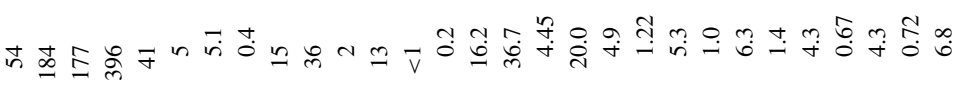

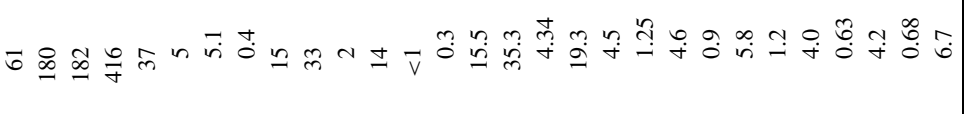
言

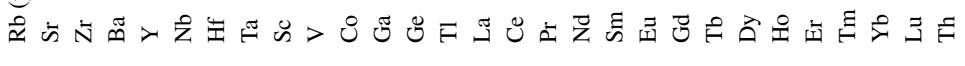




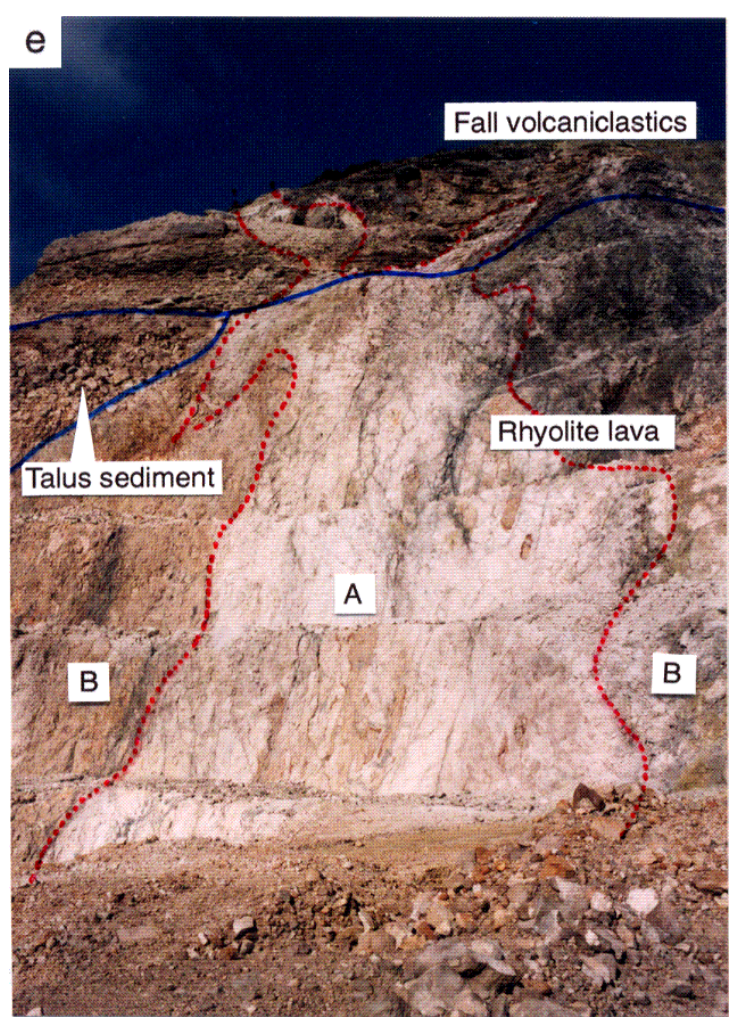

Fig. 4. e) Residual silicified zone along the fractures at the old Ohtanibira quarry. The height of the cliff is about $40 \mathrm{~m}$, and the silicified zone of $\mathrm{A}$ is $10-15 \mathrm{~m}$ wide. A and B show alteration mineral assemblages of (quartz)-tridymite-cristobalite and tridymite-cristobalite, respectively.

volcanic vapor into ground water, based on isotopic data (Shinohara et al., 1993). A similar origin of acidity is also indicated at many high-sulfidation type deposits (Vennemann et al., 1993; Hedenquist et al., 1994b; Arribas et al., 1995) and active acid crater lakes (Christenson and Wood, 1993). The second alteration type occurs as silica addition by low-temperature and much less acidic solutions on the flanks of the volcano and at the ground surface. For example, the silica cementation of volcaniclastics, ash and talus matrix observed on the surface far from the fumaroles is probably caused by silica addition. Around the summit crater, meteoric water penetrates into the already silicified rock, is heated and dissolves silica from volcanic glass at depth. After the temperature of the solution decreases silica is precipitated during flow toward the flanks. The silicacemented surface consists mostly of amorphous silica or cristobalite. Some amorphous silica veins also form by flow of low-temperature silica-rich solution.

Few clay minerals have been documented at the surface of the summit or flank. In addition, alunite is also uncommon inside the summit crater. Alunite fills the matrix of talus sediments to depth of several tens of meters around the summit crater, indicating alteration by acid aqueous solution (Hemley et al., 1969). The Al and K of alunite was probably leached and transported by acid solution, and permeated into the subsurface. According to Yoshida et al. (1976) and Kimbara et al. (1977), alunite and clay minerals were produced mainly below the water table, more than $50 \mathrm{~m}$ below the surface, based on alteration in several cores drilled
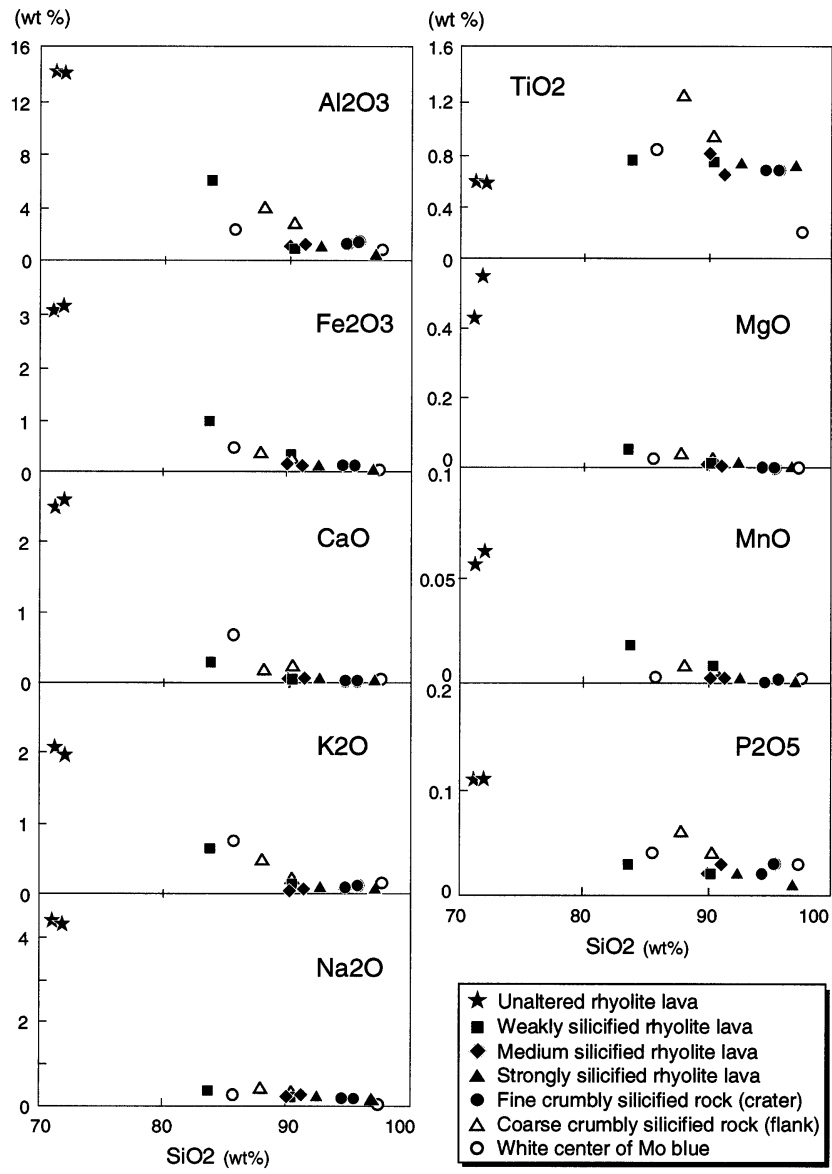

Fig. 5. $\mathrm{SiO}_{2}$-major element variation diagram of altered whole rocks.

at the foot of Iwodake. The abundant silica minerals with little alunite inside the summit crater and on the crater wall is most likely caused by the rare existence of liquid water inside the summit crater.

\subsection{Geochemistry of alteration process}

During hydrothermal alteration, the unaltered rhyolite of $\mathrm{SiO}_{2}=71-72 \mathrm{wt} \%$ was leached to form a residual silicified rock with $>90 \mathrm{wt} \% \mathrm{SiO}_{2}$. Most major elements, except for $\mathrm{TiO}_{2}$ and $\mathrm{P}_{2} \mathrm{O}_{5}$, have been largely leached during the process (Fig. 5). Hedenquist et al. (1994a) provides evidence for the isochemical dissolution of fresh Iwodake rhyolite by the acidic water. The $\mathrm{Al}_{2} \mathrm{O}_{3}, \mathrm{Fe}_{2} \mathrm{O}_{3}$ and $\mathrm{K}_{2} \mathrm{O}$ contents are completely leached at about $90 \mathrm{wt} \% \mathrm{SiO}_{2}$, and $\mathrm{CaO}, \mathrm{Na}_{2} \mathrm{O}$, $\mathrm{MgO}$ and $\mathrm{MnO}$ are also depleted at about $85 \mathrm{wt} \% \mathrm{SiO}_{2}$. Thus $\mathrm{K}$ is less mobile than other alkali elements such as $\mathrm{Ca}$ and $\mathrm{Na}$, consistent with the slightly smaller amount of $\mathrm{K}$ in the acidic water of Hedenquist et al. (1994a). Although trace elements such as $\mathrm{Rb}, \mathrm{Sr}, \mathrm{Sc}, \mathrm{Y}$, Th and $\mathrm{V}$ have been leached almost completely, $\mathrm{Ba}, \mathrm{Zr}, \mathrm{Nb}$ and $\mathrm{Hf}$ are present at concentrations close to original values (Fig. 6). Therefore LIL (large-ion lithophile) elements, except for Ba, and III B group elements in periodic table such as Sc, Y and Th have been leached. The $\mathrm{Ba}$ has not been mobilized despite its large ionic radius. All HFS (high field-strength) elements have been immobile.

All chondrite-normalized REEs show almost equal depletion without fractionation, except for $\mathrm{Eu}$, with increasing of 

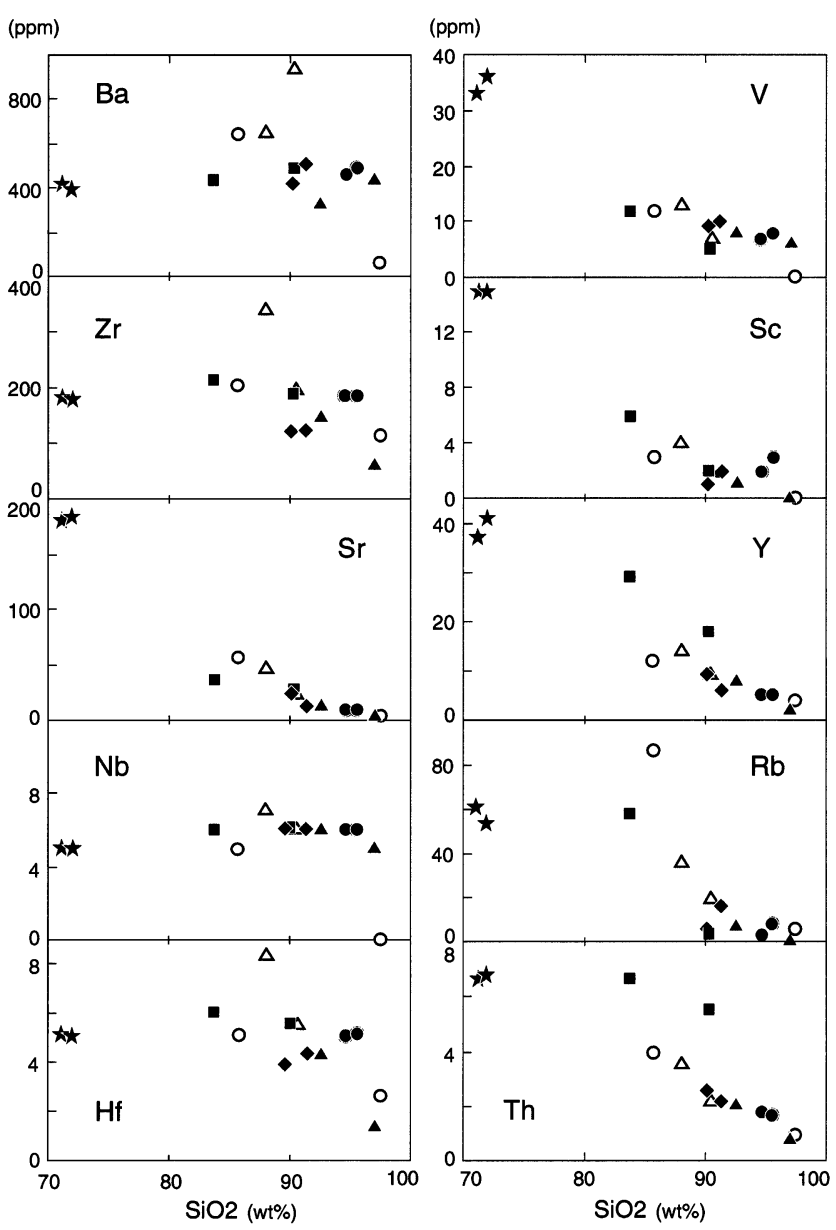

Fig. 6. $\mathrm{SiO}_{2}$-trace element variation diagram of altered whole rocks. Legend is same as the Fig. 5.

silici cation (Fig. 7(a)). Such depletion in the silici ed samples may be caused by the absence of secondary minerals, such as alunite or clay minerals, which can host the REE in their structures. But the unaltered rhyolite-normalized patterns reveal that leaching of light REEs is slightly greater than the heavy REEs (Fig. 7(b)). Fulignati et al. (1999) also reported REE depletion pattern without fractionation in silicic facies. On the other hand, Arribas et al. (1995) showed an obvious depletion of heavy REEs in leached, vuggy quartz of high-sul dation ore deposits.

At relatively low temperature $\left(<300^{\circ} \mathrm{C}\right)$ and low $\mathrm{pH}$ with an abundance of sulfur, sulfate can be the major species of the REE complex (Wood, 1990; Lewis et al., 1998). In contrast, at a $\mathrm{pH}$ of 2 and high activity of sulfate, even the very high content of chloride species does not appear to affect the complexing of REE (Lewis et al., 1998). The volcanic gases from Iwodake lead to a high content of sulfate and chloride but low ratio of sulfate to chloride (Matsubaya et al., 1975; Shinohara et al., 1993). In addition, the acid hot springs with a $\mathrm{pH}<2$ around Iwodake also show similar chemical characteristics to the volcanic gases (Kamada et al., 1974; Shinohara et al., 1993). The presence of alunite beneath Iwodake also indicates a high activity of sulfate in the acid solution. Therefore, the REE most likely was complexed mainly by sulfate in the low $\mathrm{pH}$ hydrothermal uid during

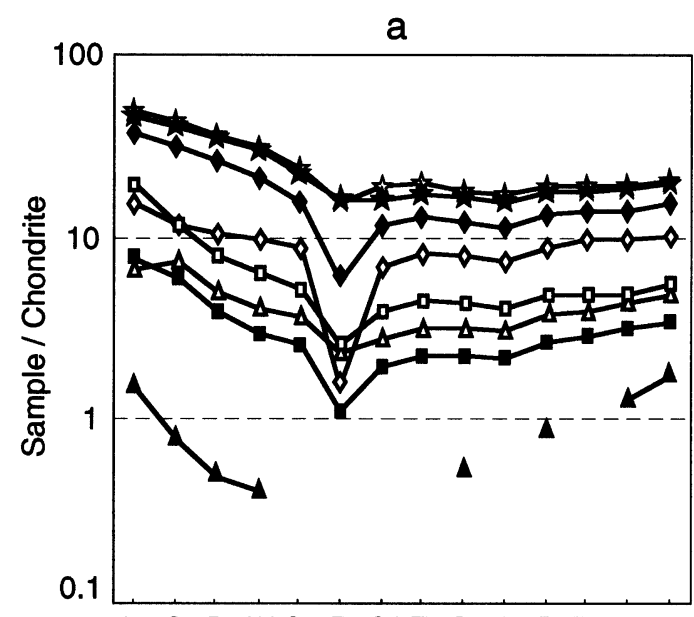

La Ce Pr Nd Sm Eu Gd Tb Dy Ho Er Tm Yb Lu

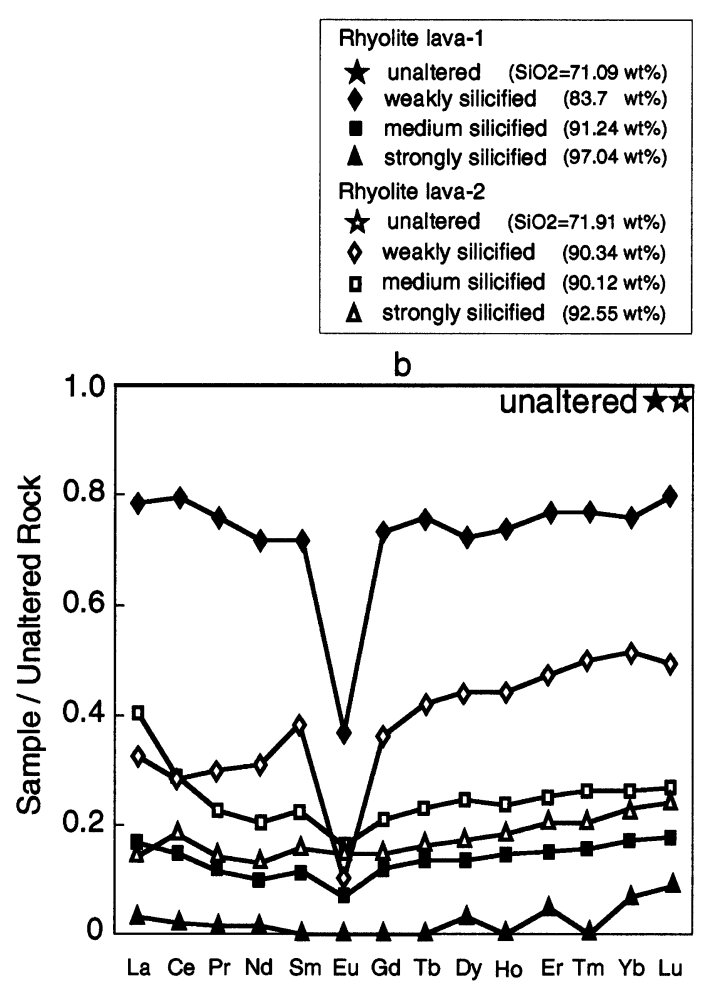

Fig. 7. REE pattern of altered rhyolite lava normalized to chondrite (a) and unaltered rhyolite (b) of Iwodake.

the silici cation of Iwodake rhyolite. In addition, sulfate species preferentially complex with the light REEs in a low pH uid (Lewis et al., 1998; Johannesson and Lyons, 1995), consistent with the result of this study (Fig. 7(b)). A high activity of uoride also affects complexing with heavy REEs (Lewis et al., 1997, 1998). However, the very high sulfate to uoride ratios in the volcanic gases and acid spring water of Iwodake are considered to have little affect on REE complexing. The large Eu negative anomaly is perhaps caused by the leaching of Eu-rich plagioclase.

There are high contents of $\mathrm{As}$ and $\mathrm{Pb}$ and slightly lower Mo and $\mathrm{Sn}$ in high-temperature $\left(>700^{\circ} \mathrm{C}\right)$ fumaroles of Iwodake (Hedenquist et al., 1994a). By contrast, Mo and $\mathrm{Pb}$ and slightly less $\mathrm{Bi}, \mathrm{Zn}$ and $\mathrm{Sn}$ are concentrated in the molybdenum blue sublimates (Figs. 8(a), (b)). The metal content pattern between the rock samples near the acidic Hi- 
Table 3. Metal content of representative altered whole rocks.

\begin{tabular}{|c|c|c|c|c|c|c|c|c|c|}
\hline \multirow{3}{*}{ ppm } & \multicolumn{9}{|c|}{ Inside of summit crater } \\
\hline & \multicolumn{2}{|c|}{$\begin{array}{l}\text { White center } \\
\text { of Mo blue }\end{array}$} & \multicolumn{3}{|c|}{ Mo blue } & \multicolumn{2}{|c|}{$\begin{array}{l}\text { Silici ed breccia } \\
\text { with sulfur matrix }\end{array}$} & \multicolumn{2}{|c|}{$\begin{array}{l}\text { Fine crumbly } \\
\text { silici ed rock }\end{array}$} \\
\hline & $022403-1$ & $022409-1$ & SIJ-1 & $022403-2$ & $022402-3$ & 98110909 & 98110914 & 98110813 & 08110923 \\
\hline No. (Table 1) & 2 & 3 & 4 & 5 & 6 & & & 7 & 8 \\
\hline $\mathrm{Au}(\mathrm{ppb})$ & 29 & $<2$ & $<2$ & 2 & $<2$ & $<2$ & $<2$ & $<2$ & $<2$ \\
\hline $\mathrm{Ag}$ & 1.5 & 1.1 & 12.6 & 4.3 & 9.1 & $<0.2$ & $<0.2$ & $<0.2$ & $<0.2$ \\
\hline As & 32 & 4 & 70 & 4 & 143 & 8 & 20 & 11 & 16 \\
\hline $\mathrm{Sb}$ & 0.4 & 0.2 & 1.5 & $<0.2$ & 0.9 & 0.3 & 0.4 & $<0.2$ & $<0.2$ \\
\hline $\mathrm{Bi}$ & 120 & 113 & 3650 & 0.3 & 209 & 32.3 & 29.5 & 3.2 & 12.2 \\
\hline $\mathrm{Cu}$ & 67 & 7 & 15 & 29 & 14 & 7 & 6 & 7 & 6 \\
\hline $\mathrm{Pb}$ & 743 & 66 & 6750 & 65 & 1100 & 24 & 56 & 25 & 23 \\
\hline $\mathrm{Zn}$ & 695 & 5 & 18 & 1860 & 224 & 10 & 8 & 7 & 7 \\
\hline Mo & 364 & 34 & 4390 & 78 & 7820 & 39 & 89 & 36 & 33 \\
\hline $\mathrm{Cd}$ & 7.4 & 2.7 & 45.4 & 7.6 & 38.9 & 0.5 & 0.7 & 0.7 & 0.6 \\
\hline $\mathrm{Hg}(\mathrm{ppb})$ & 553 & 187 & 1360 & 345 & 630 & $<10$ & 25 & $<10$ & $<10$ \\
\hline Sn & 82 & 37 & 442 & $<10$ & 188 & $<10$ & 12 & $<10$ & $<10$ \\
\hline W & 59 & $<10$ & 22 & 13 & 116 & $<10$ & 12 & $<10$ & $<10$ \\
\hline $\mathrm{Se}$ & 2.4 & $<0.1$ & 27.2 & $<0.1$ & 25.6 & 4.9 & 2.6 & $<0.1$ & $<0.1$ \\
\hline $\mathrm{Te}$ & $<0.1$ & $<0.1$ & $<0.1$ & $<0.1$ & $<0.1$ & $<0.1$ & $<0.1$ & $<0.1$ & $<0.1$ \\
\hline $\mathrm{Fe}(\%)$ & 0.32 & 0.03 & 0.35 & 1.12 & 25.5 & 0.02 & 0.06 & 0.09 & 0.09 \\
\hline $\mathrm{Ti}$ & 3780 & 1130 & 3560 & 4650 & 1800 & 818 & 9140 & 2670 & 2540 \\
\hline
\end{tabular}

\begin{tabular}{|c|c|c|c|c|c|c|c|c|c|c|c|c|}
\hline \multirow{3}{*}{ ppm } & \multicolumn{6}{|c|}{ Around summit crater } & \multirow{2}{*}{\multicolumn{3}{|c|}{$\frac{\text { Around summit }}{\text { Amorphous silica }} \stackrel{ }{\text { vein }}$}} & ank & \multicolumn{2}{|c|}{ Higashi hot spring } \\
\hline & \multicolumn{2}{|c|}{$\begin{array}{c}\text { Strongly silici ed } \\
\text { rhyolite lava }\end{array}$} & \multicolumn{2}{|c|}{$\begin{array}{c}\text { Weakly silici ed } \\
\text { rhyolite lava }\end{array}$} & \multicolumn{2}{|c|}{$\begin{array}{c}\text { Unaltered } \\
\text { rhyolite lava }\end{array}$} & & & & $\begin{array}{l}\text { Crumbly } \\
\text { silici ed }\end{array}$ & $\begin{array}{l}\text { Silici e } \\
\text { of talus }\end{array}$ & $\begin{array}{l}\text { matrix } \\
\text { ediment }\end{array}$ \\
\hline & 08110801 & 99112111 & 08110805 & 99112103 & 98110803 & 99112102 & $98110801^{\prime}$ & 98111005 & 99112004 & 98111004 & 98111135 & 99111909 \\
\hline No. (Table 1) & 12 & 13 & 16 & 17 & 20 & 21 & 28 & 29 & 30 & 32 & & \\
\hline $\mathrm{Au}(\mathrm{ppb})$ & $<2$ & $<2$ & $<2$ & $<2$ & $<2$ & $<2$ & $<2$ & $<2$ & $<2$ & $<2$ & $<2$ & $<2$ \\
\hline $\mathrm{Ag}$ & $<0.2$ & 0.4 & 0.2 & $<0.2$ & 0.3 & $<0.2$ & $<0.2$ & $<0.2$ & $<0.5$ & 0.5 & 0.5 & $<0.2$ \\
\hline As & $<1$ & $<1$ & 1 & $<1$ & 3 & 2 & & $<1$ & $<1$ & $<1$ & 52 & 57 \\
\hline $\mathrm{Sb}$ & $<0.2$ & $<0.2$ & $<0.2$ & $<0.2$ & $<0.2$ & $<0.2$ & $<0.2$ & $<0.2$ & $<0.2$ & $<0.2$ & $<0.2$ & $<0.4$ \\
\hline $\mathrm{Bi}$ & $<0.1$ & $<0.1$ & 0.5 & $<0.1$ & 5.3 & 1.0 & $<0.1$ & $<0.1$ & $<0.1$ & $<0.1$ & 10.8 & 7.6 \\
\hline $\mathrm{Cu}$ & 2 & 4 & 3 & 3 & 4 & 13 & 1 & 2 & 1 & 3 & 3 & 4 \\
\hline $\mathrm{Pb}$ & 12 & 9 & 19 & 12 & 23 & 21 & 10 & 2 & 4 & 20 & 25 & 14 \\
\hline $\mathrm{Zn}$ & 20 & 13 & 36 & 22 & 65 & 136 & 86 & 4 & 4 & 16 & 30 & 29 \\
\hline Mo & 4 & 3 & 5 & 6 & 5 & $<1$ & $<1$ & $<1$ & $<1$ & 5 & $<1$ & 8 \\
\hline $\mathrm{Cd}$ & $<0.1$ & $<0.1$ & $<0.1$ & $<0.1$ & $<0.1$ & $<0.1$ & $<0.1$ & $<0.1$ & $<0.1$ & $<0.1$ & $<0.1$ & $<0.1$ \\
\hline $\mathrm{Hg}(\mathrm{ppb})$ & $<10$ & $<10$ & $<10$ & 494 & 292 & 162 & $<10$ & $<10$ & $<10$ & 413 & 607 & 151 \\
\hline $\mathrm{Sn}$ & $<10$ & $<10$ & $<10$ & $<10$ & $<10$ & $<10$ & $<10$ & $<10$ & $<10$ & $<10$ & $<10$ & $<10$ \\
\hline W & $<10$ & $<10$ & $<10$ & $<10$ & $<10$ & $<10$ & $<10$ & $<10$ & $<10$ & $<10$ & $<10$ & $<10$ \\
\hline $\mathrm{Se}$ & $<0.1$ & $<0.1$ & $<0.1$ & $<0.1$ & 0.3 & $<0.1$ & $<0.1$ & $<0.1$ & $<0.1$ & $<0.1$ & $<0.1$ & $<0.1$ \\
\hline $\mathrm{Te}$ & $<0.1$ & $<0.1$ & $<0.1$ & $<0.1$ & $<0.1$ & $<0.1$ & $<0.1$ & $<0.1$ & $<0.1$ & $<0.1$ & $<0.1$ & $<0.1$ \\
\hline $\mathrm{Fe}(\%)$ & 0.03 & 0.12 & 0.63 & 0.24 & 1.95 & 2.1 & $<0.01$ & $<0.01$ & 0.04 & 0.3 & 10.9 & 25.2 \\
\hline $\mathrm{Ti}$ & 4300 & 4400 & 4470 & 4640 & 3480 & 3550 & 16 & 1100 & 513 & 7020 & 2390 & 1290 \\
\hline
\end{tabular}

gashi spring (Fig. 8(e)) and acidic spring water at the foot of Iwodake (Hedenquist et al., 1994a) are similar. The trend of acidic spring water and the high-temperature fumaroles (Hedenquist et al., 1994a) are similar except for Au and $\mathrm{Cu}$. In the molybdenum blue and rocks inside the summit crater, Mo concentration is high, whereas As is low despite its high concentration in the high-temperature fumaroles and acid spring water (Figs. 8(a), (b), (c)). Therefore, except for precious metals such as $\mathrm{Au}$ and $\mathrm{Cu}$, most metals have been leached and transported to the foot of Iwodake. Inside the summit crater, Mo was largely deposited as molybdenum blue sublimate from the high-temperature fumaroles, whereas most As discharged together with volcanic gases. The very high Fe concentration in the rock samples near the Higashi spring (Fig. 8(e)) was caused by leaching from surrounding rocks during the movement of the acidic water toward the foot of the mountain.

\subsection{Direction of alteration and geological structure}

The fractures in the summit crater wall and around the crater have two trends, NE-SW and NW-SE, with the fractures of the NE-SW trend dominant (Fig. 3). Yoshida et al. (1976) also suggested the same directions for two structural lines under Iwodake volcano. Many fumaroles and molybdenum blue sublimates are also concentrated along the NE-SW trend (Fig. 2). Figure 10(a) shows zones of concentrated fractures, based on the distribution of fumaroles, fractures and alteration areas around the summit crater of Iwodake. Major erosion of the ank also develops along the same direction as concentrated fractures. In addition, concentration area of fractures (Fig. 10(b)) is parallel to the caldera rim and the trend of Shin-Iwojima, Iwodake and Inamuradake, which are post-caldera cones. Therefore, it is likely that fractures parallel to the caldera rim are pathways for the ascending volcanic gases and hydrothermal solution (Hamasaki, 1999). Indeed, Ketsunohama coast-line, which 


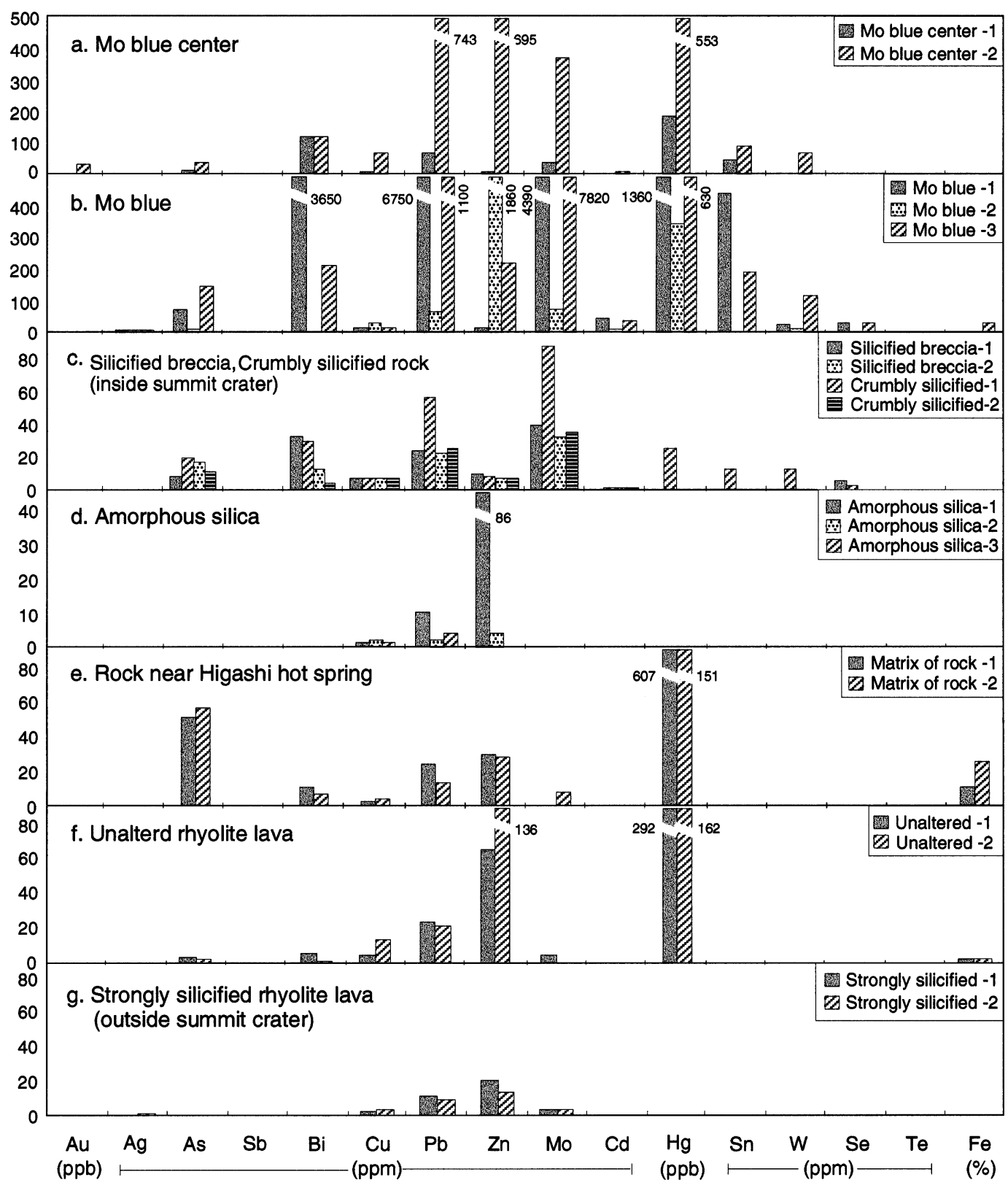

Fig. 8. Metal content diagram of altered whole rocks.

\begin{tabular}{|c|c|c|c|c|c|c|c|c|}
\hline \multirow{2}{*}{ Minerals Locality } & \multicolumn{2}{|c|}{ Inside summit crater } & \multirow{2}{*}{ Around crater } & \multicolumn{2}{|c|}{ Subsurface } & \multirow{2}{*}{$\begin{array}{l}\text { Ground } \\
\text { surface }\end{array}$} & \multirow{2}{*}{$\begin{array}{r}\text { Silica } \\
\text { vein }\end{array}$} & \multirow{2}{*}{ Flank } \\
\hline & Central part & Crater wall & & shallow & deep & & & \\
\hline \multicolumn{9}{|l|}{ Native sulfur } \\
\hline \multicolumn{9}{|l|}{ Quartz } \\
\hline \multirow{2}{*}{\multicolumn{9}{|c|}{ Tridymite }} \\
\hline & & & & & & & & \\
\hline \multicolumn{9}{|l|}{$\alpha$-Cristobalite } \\
\hline \multicolumn{9}{|l|}{ Alunite } \\
\hline Amorphous & & & & & & & & \\
\hline silica & & & & & & & & \\
\hline
\end{tabular}

Fig. 9. Mineral assemblages of altered rocks near and on the surface of Iwodake volcano. 


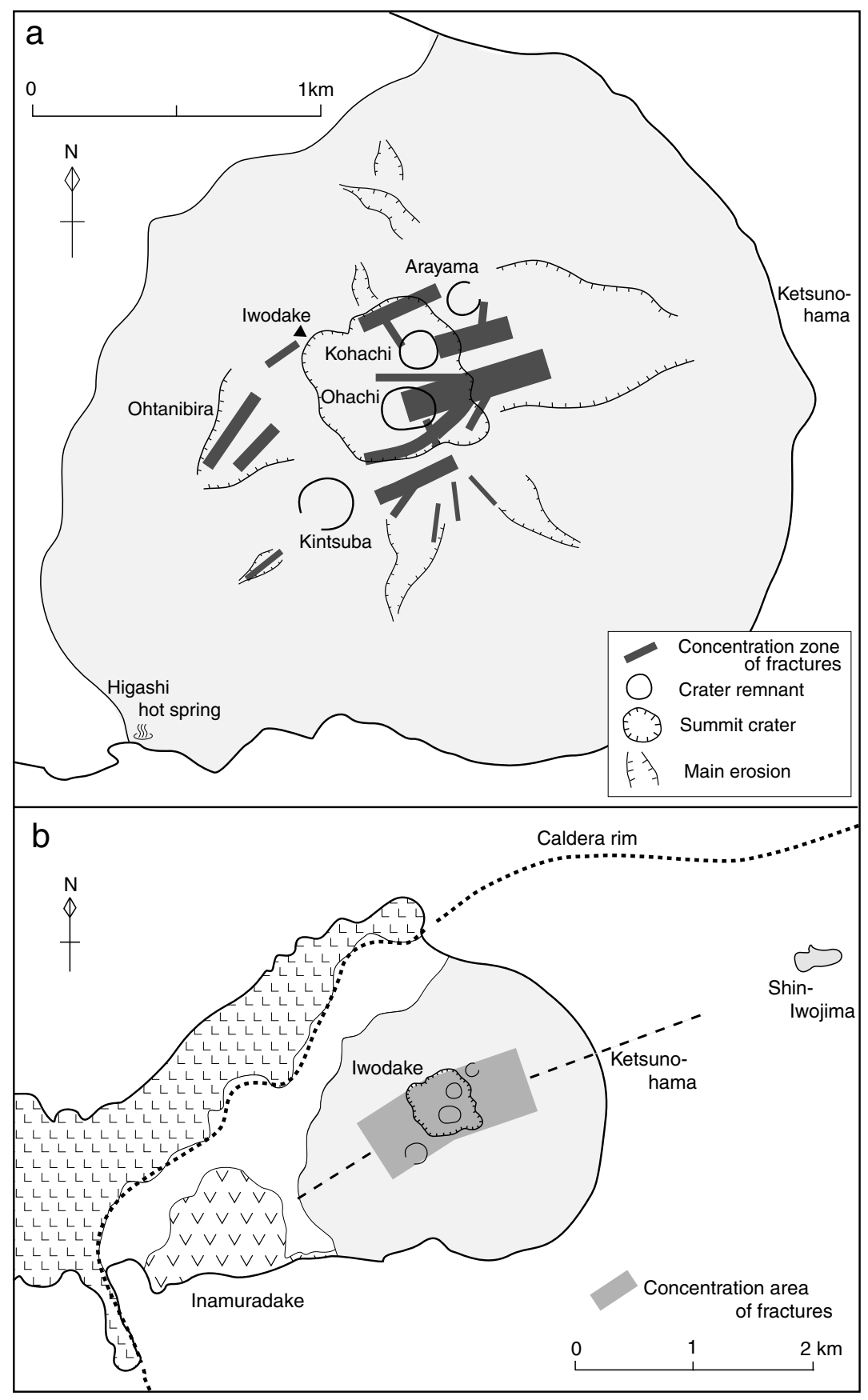

Fig. 10. a) Zone of concentrated fractures determined by the distribution of the fumaroles, fractures and altered areas around the summit crater of Iwodake. Main eroded topography also shown. b) Relation of area of fractures around Iwodake to the Kikai caldera rim.

has the most hot springs, also lies between Shin-Iwojima and Inamuradake. Futhermore, high anomalies of $\mathrm{CO}_{2}$ content in the soil occur not only at the caldera rim but on the Ketsunohama coast and between Iwodake and Inamuradake (Shimoike et al., 2000). These facts support the possibility that there is tectonic line along Shin-Iwojima, Iwodake and Inamuradake.

The direction of fractures on the western side of the summit crater, including Ohtanibira, is NE-SW and changes to ENE-WSW on the eastern side. In addition, several crater remnants around the summit, such as Kintsuba, Kohachi and Arayama plus the active Ohachi crater, lie along the domi- nant NE-SW direction (Fig. 10(a)). Alteration evidence indicates that Ohtanibira was an area of high-temperature fumaroles, although activity is now weak. High-temperature fumaroles are now located inside and on the eastern side of the summit crater. Therefore, it appears that several craters once located along the NE-SW direction, and volcanic gases were also discharged along the same direction fractures. This direction of fractures has now changed to ENE-WSW and the active fumarolic area moved to the eastern part of the summit crater.

Acknowledgments. The author thanks Drs. H. Shinohara, Y. 
Kawanabe, G. Saito, K. Kazahaya, Y. Nishi and Y. Matsushima, Geological Survey of Japan, for their useful comments on the geology and volcanic gases, and for support of the survey at SatsumaIwojima. I also thank Dr. H. Kamioka for useful comments on REE. The manuscript has bene ted from constructive reviews from Drs. J. W. Hedenquist, A. Arribas, Jr. and T. E. C. Keith.

\section{References}

Arribas, A., Jr., C. G. Cunninham, J. J. Rytuba, R. O. Rye, W. C. Kelly, M. H. Podwisocki, E. H. McKee, and R. M. Tosdal, Geology, geochronology, uid inclusions, and isotope geochemistry of the Rodalquilar gold alunite deposit, Spain, Economic Geology, 90, 795-822, 1995.

Christenson, B. W. and C. P. Wood, Evolution of a vent-hosted hydrothermal system beneath Ruapehu Crater Lake, New Zealand, Bulletin of Volcanology, 55, 547-565, 1993.

Fulignati, P., A. Gioncada, and A. Sbrana, Rare-earth element (REE) behaviour in the alteration facies of the active magmatic-hydrothermal systm of Vulcano (Aeolian Islands, Italy), J. Volcanol. Geotherm. Res., 88, 325-342, 1999.

G.S.J. (Geological Survey of Japan) and Kyoto University, Recent volcanic activity at the summit of Iwodake, Satsuma-Isojima until Nov. 1997, Report of Coordinating Committee for Prediction of Volcanic Eruption, 70, 59-61, 1998 (in Japanese).

Hamasaki, S., The distribution and direction of the alteration zone in and around the crater at Satsuma-Iwojima volcano, Program and abstracts, The Volcanological Society of Japan, 1999, 2, 90, 1999 (in Japanese).

Hedenquist, J. W., M. Aoki, and H. Shinohara, Flux of volatiles and oreforming metals from the magmatic hydrothermal system of Satsuma Iwojima volcano, Geology, 22, 585-588, 1994a.

Hedenquist, J. W., Y. Matsuhisa, E. Izawa, N. White, W. F. Giggenbach, and M. Aoki, Geology, geochemistry, and origin of high sul dation $\mathrm{Cu}$ Au mineralization in the Nansatsu district, Japan, Economic Geology, 89, 1-30, 1994b.

Hemley, J. J., P. B. Hostetler, A. J. Gude, and W. T. Mountjoy, Some stability relations of alunite, Economic Geology, 64, 599-612, 1969.

Johannesson, K. H. and W. B. Lyons, Rare-earth element geochemistry of Colour Lake, an acidic freshwater lake on Axel Heiberg Island, Northwest Territories, Canada, Chemical Geology, 119, 209-223, 1995.

Kamada, M., H. Sakamoto, and T. Onishi, Geochemical studies on Iwojima volcano (Kagoshima Pref.) Part 1. Chemical composition, temperature, and discharge of Higashi hot spring, and their variation, Onsenkougakukaisi, 9, 117-124, 1974 (in Japanese with English abstract).

Kawanabe, Y., ${ }^{14} \mathrm{C}$ dating of the Io-dake pyroclastic ow deposits, Satsuma Iojima volcano, Japan, Report of Coordinating Committee for Prediction of Volcanic Eruption, 75, 115, 2000 (in Japanese).

Kimbara, K., H. Shigeno, and T. Okubo, Hydrothermal alteration of Satsuma-Iwojima, Chishitsu News, 272, 9-17, 1977 (in Japanese).

Lewis, A. J., M. R. Palmer, N. C. Sturchio, and A. J. Kemp, The rare earth element geochemistry of acid-sulphate and acid-sulphate-chloride geothermal systems from Yellowstone National Park, Geochim. Cosmochim. Acta, 61, 695-706, 1997.

Lewis, A. J., A. Komninou, B. W. Yardley, and M. R. Palmer, Rare earth element speciation in geothermal uids from Yellowstone National Park, Wyoming, USA, Geochim. Cosmochim. Acta, 62, 657-663, 1998.

Machida, H. and F. Arai, Akahoya Ash-A holocene widespread tephra erupted from the Kikai Caldera, South Kyushu, Japan, Quaternary Research, 17, 143-163, 1978 (in Japanese with English abstract).

Matsubaya, O., A. Ueda, M. Kusakabe, Y. Matsuhisa, H. Sakai, and A. Sasaki, An isotopic study of the volcanoes and the hot springs in Satsuma Iwo-jima and some areas in Kyushu, Bull. Geological Survey of Japan, 26, 375-392, 1975 (in Japanese with English abstract).

Matsumoto, T., Submarine eruptions on the Iwo-ga-Shima and the geology of the island and its surroundings, Bull. Volcanol. Soc. Japan, 3, 144162, 1937 (in Japanese).

Matsuo, S., T. Suzuki, M. Kusakabe, H. Wada, and M. Suzuki, Isotopic and chemical composition of volcanic gases from Satsuma-Iwojima, Japan, Geochemical J., 8, 165-173, 1974.

Nogami, K., M. Yoshida, and J. Ossaka, Chemical composition of discolored seawater around Satsuma-Iwojima, Kagoshima, Japan, Bull. Volcanol. Soc. Japan, 38, 71-77, 1993.

Notsu, K., K. Ono, and T. Soya, Strontium isotopic relations of bimodal volcanic rocks at Kikai volcano in Ryukyu arc, Japan, Geology, 15, 345348, 1987.

Ono, K., T. Soya, and T. Hosono, Geology of Satsuma-Io-jima district, quadrangle series, scale 1:50000, Tanegashima (16) No. 2, Geological Survey of Japan, 80 p, 1982 (in Japanese with English abstract).

Saito, E., Topographical map around Mt. Iwodake volcano, Open le report of Geological Survey of Japan, 308, 1998 (in Japanese).

Shimoike, Y., K. Kazahaya, and H. Shinohara, Soil $\mathrm{CO}_{2}$ emission at Satsuma-Iwojima volcano, Japan, Program and abstracts, The Volcanological Society of Japan, 2000, 2, 134, 2000 (in Japanese).

Shinohara, H., W. F. Giggenbach, K. Kazahaya, and J. W. Hedenquist, Geochemistry of volcanic gases and hot springs of Satsuma-Iwojima, Japan: Following Matsuo, Geochemical J., 27, 271-285, 1993.

Shinohara, H., K. Kazahaya, N. Matsushima, Y. Nishi, G. Saito, and Y. Kawanabe, Recent volcanic activity at the summit of Iwodake, SatsumaIwojima until November 1998, Report of Coordinating Committee for Prediction of Volcanic Eruption, 73, 104-105, 1999 (in Japanese).

Ueda, A. and T. Itaya, Microphenocrystic pyrrhotite from dacite rocks of Satsuma-Iwojima, southwest Kyushu, Japan and Solubility of Sulfur in Dacite Magma, Contrib. Mineral. Petrol., 78, 21-26, 1981.

Vennemann, T. W., J. L. Muntean, S. E. Kesler, J. R. O’Neil, J. W. Valley, and N. Russell, Stable isotope evidence for magmatic uids in the Pueblo Viejo epithermal acid sulfate $\mathrm{Au}-\mathrm{Ag}$ deposit, Dominican Republic, Economic Geology, 88, 55-71, 1993.

Wood, S. A., The aqueous geochemistry of the rare-earth elements and yttrium: 2 Theoretical predictions of speciation in hydrothermal solutions to $350^{\circ} \mathrm{C}$ at saturation water vapor pressure, Chemical Geology, 88, 99125, 1990.

Yoshida, M., T. Ozawa, and J. Ossaka, Molybdenum minerals-molybdenum blue and molybdenite-formed as volcanic sublimates at SatsumaIwo-jima volcano, Jour. Chem. Soc. Japan, 1972, 575-583, 1972 (in Japanese with English abstract).

Yoshida, T., K. Higuchi, and K. Yuhara, Alteration of rocks by geothermal activities in Satsuma Iwo-jima Island, Kagoshima Prefecture, Japan, Chinetsu, 13, 9-19, 1976 (in Japanese with English abstract).

S. Hamasaki (e-mail: hamasaki-st@aist.go.jp) 